\title{
External knowledge and performance of offshore IT service providers in India: The mediating role of talent management
}

\begin{abstract}
The global shortage of IT professionals has been identified as one of the most serious threats against the continued growth of Offshore IT service providers (OSPs). As a result, talent management has become a key competitive strategy for OSPs. However, how talent management contributes towards the performance of OSPs remains poorly understood, particularly in relation to its interaction with knowledge. To examine this issue, we draw on a sample of 68 OSPs in India to test the effects of talent management and external knowledge on performance. The results confirm that both external knowledge and talent management are positively related to firm performance and that the latter has strong mediating effects on the relationship between external knowledge and firm performance. The results suggest that OSPs should consider talent management as a mechanism through which knowledge resources can be exploited to enhance firm performance. The managerial implications and limitations of the findings are also discussed.
\end{abstract}

Keywords: Offshore service providers, knowledge, talent management, firm performance, India.

This is the final version of the paper accepted by the journal Please cite this paper as Chadee, D., \& Raman, R. (2012). External knowledge and performance of offshore IT service providers in India: The mediating role of talent management. Asia Pacific Journal of Human Resources (50), 459-482, doi:10.1111/j.1744-7941.2012.00039.x.

Published paper available at: 10.1111/j.1744-7941.2012.00039.x

\section{*Corresponding author}

We thank NASSCOM for its assistance with the survey for this study; Education New Zealand for financial support; and the University of Auckland for hosting the project. We also thank Mohan Subramaniam (Boston College), Siah Ang Hwee (University of Auckland), two anonymous reviewers and the editors of the special issue for their helpful comments. The authors assume full responsibility for any errors and omissions in the paper. 


\section{Introduction}

International outsourcing of information technology (IT) services has experienced rapid growth in recent years. The global IT services market has been estimated to be worth approximately US $\$ 800$ billion and growing at a compounded 5.8\% annually (Gartner 2006; OECD 2006). It has also been estimated that a mere $10 \%$ of the potential market has so far been realised (McKinsey 2005). Growth in this market has been driven by firms in advanced industrialised countries outsourcing IT services to IT service providers mostly located in developing and emerging economies. On the demand side, the USA (37\%), Western Europe (35\%) and Japan (15\%) are the main clients for offshore IT service providers (EITO 2006). On the supply side, India, China, Malaysia and the Philippines are among the key offshore IT service providers (OSPs) (Chadee \& Raman 2009). Among these countries, India accounts for almost two-thirds of the global IT services offshoring market (UNCTAD 2009). The IT services offshoring market in India grew at a compound annual rate of more than $22 \%$ in 2010 and is expected to grow by more than 26\% in 2013 (Deblina 2010; IDFC 2010; Shukla 2010). The dominance and rapid growth of OSPs in India (Thite \& Russell 2010) raise important questions regarding the sources of competitiveness of Indian OSPs in particular as well as the competitiveness of OSPs from developing countries in general. Despite the rapid development of the global IT services sector and the rise of India as a preferred destination for outsourcing IT services, research which focuses specifically on the competitiveness of Indian OSPs remains scant to date (Raman \& Chadee 2011).

According to the resource-based view of the firm (Barney 1991, 2001), a firm draw its competitiveness from resources that are rare, inimitable, non substitutable and non transferable. There is agreement in the literature that knowledge and human capital are resources and capabilities which meet these criteria (Becker \& Huselid 2006). More recently, 
the debate on the contribution of human resources to organisational performance has shifted from traditional human resource related sources of competitiveness to a greater emphasis on talent management (Boudreau \& Ramstad 2007; Cheese, Thomas \& Craig 2008; Collings, Scullion \& Vaiman 2011; Vance \& Vaiman 2008). Accordingly, since the resources and capabilities that underpin a firm's competitive advantage are directly tied to the capabilities of talented individuals (Collings \& Mellahi 2009), firms can benefit by focusing specifically on managing specific talents within the organisation. As a result, talent management has received increasing attention since its inception in the late 1990s (see Axelrod, HandfieldJones \& Michaels 2002; Collings \& Mellahi 2009) and has been accompanied by an abundance of research on the subject. There is now wide agreement among practitioners and researchers that talent management constitutes one of the greatest challenges faced by organisations in the coming decade (Mellahi \& Collings 2010; Tymon, Stumpf \& Doh 2010). Knowledge-intensive firms such as professional service providers, in particular, are vulnerable to the global shortage of skilled professionals which is particularly acute in the IT sector. Hence, talent management has become a strategic weapon for OSPs in sustaining their competitiveness. This is particularly relevant for Indian OSPs where employee turnover rates of as much as $40 \%$ are not uncommon (Thite \& Russell 2010).

Knowledge has also been identified as a critical source of competitive advantage (Barney 2001; Nonaka 1994). Firms generally have access to two main sources of knowledge, namely, internal sources such as their own internal knowledge management systems; and external sources such as academic and research institutions, consulting firms and trade bodies. While the roles of internal knowledge management systems and processes have been well researched and have been found to contribute positively to firm performance, the role of external sources of knowledge remains poorly understood (Powell 1998). External 
knowledge is particularly important in the context of developing countries, where formal institutions and infrastructure similar to those in Western industrialised countries either do not exist or are underdeveloped. Because of the institutional voids faced by firms from developing countries, they tend to rely on external formal and informal networks for knowledge acquisition and sharing (Peng, Wang \& Jiang 2008). In the case of OSPs in India, developing and maintaining external networks have been found to be critical elements of competitiveness for the largest OSPs in the country (Chadee, Raman \& Michailova 2011). However, external knowledge by itself does not necessarily translate into better performance unless it is properly assessed, analysed and utilised in a way which benefits the organisation. In this regard, talented staff who are able to transform external knowledge into superior performance become critical for the competitiveness of the organisation. Although a strong case exists to suggest that talent management plays a mediating role between external knowledge and firm performance, no empirical evidence exists to date to confirm this. The role of talent management on the effects of knowledge on firm performance, which is the main focus of this paper, has been largely overlooked in the literature to date, particularly for knowledge intensive firms such as OSPs, where people and knowledge constitute the key resources of the organisation.

The main objective of this paper is to test the mediating effects of talent management on the relationship between external knowledge and the performance of OSPs in India. The paper contributes to the literature in several ways. First, although it is well established that knowledge-intensive, people-based organisations, such as OSPs, rely predominantly on knowledge and human capital for firm success, the interplay between these two main firmspecific resources has not been investigated. The need to address this gap has also been identified and highlighted in several recent studies (see Vance \& Vaiman 2008; Whelan \& 
Carcary 2011). The main contention of the paper is that talent management mediates the effects of external knowledge on performance by acting as the mechanism through which external knowledge is transformed into better performance. Second, the role of external knowledge has not been fully investigated in relation to its effects on performance. The extensive empirical literature on knowledge management and firm performance does not explicitly differentiate between internal and external knowledge. This differentiation is particularly relevant for firms in developing countries where, due to the institutional environment, they tend to rely on formal and informal external networks for knowledge acquisition (Peng, Wang \& Jiang 2008). Furthermore, increasingly, firms seek out knowledge from external sources because of the realisation that firms have limited capacity to produce all the required knowledge internally in order to sustain their competitiveness. In these respects, there is a growing recognition of the strategic role of external knowledge, particularly of the tacit type, in firm performance. Third, the paper contributes towards the talent management literature from an empirical standpoint. The talent management literature, which is in its early stages of development, has so far dealt extensively with definitional and conceptual issues to clearly differentiate talent management from traditional human resource management and strategic human resource management. This paper adds to the conceptual developments in the talent management literature by undertaking empirical analysis of some of the talent management concepts. In addition, research on OSPs is also in its infancy and this paper adds to the growing literature on the performance of OSPs in general, and OSPs from India in particular. Estimates by McKinsey (2005) suggest that in 2005 only 10 percent of the IT offshoring market had been realised. With this in mind, the offshoring of IT services will continue to grow and the competitive nature of the industry will also likely experience change as new entrants join the industry. Thus, greater insights into the dynamics of the IT offshoring industry are valuable for both practitioners and academics. Further, the paper 
makes a major contribution to the scant research literature on Indian firms in general and OSPs in particular. Although India is rapidly emerging as a growing economic power, and the global IT offshoring market is dominated by Indian firms, little research exists on the conduct and performance of Indian firms. The context within which Indian firms develop and grow to become dominant global players has also received little research attention.

The rest of the paper is structured as follows. In the next section, the theoretical considerations and hypotheses are presented. We then describe the research methods and data followed by the analysis and discussion of results. The conclusions are discussed along with the limitations and managerial implications in the last section.

\section{Theoretical considerations and hypotheses}

Human resource management (HRM) can be distinguished from talent management (TM) in terms of the former being the 'professional practice' and the latter the 'decision science' (Boudreau \& Ramstad 2005a, 2005b, 2005c). A decision science connects organisational decisions to its success and, in this sense, TM is a decision science as it enhances decisions about talents within and outside the HR function (see Boudreau \& Ramstad 2005b) for better organisational performance. As a decision science, TM takes a more systemic approach where HR processes are systematically related to strategic decisions and organisational performance (Boudreau \& Ramstad 2005a, 2005b, 2005c). Collings and Mellahi (2009) identify three elements of TM. They include the identification of pivotal positions, development of a talent pool and the existence of a differentiated human resource architecture. Talent segmentation - identifying 'pivotal talent pools' - is as critical as 'customer segmentation' in marketing (Boudreau \& Ramstad 2005b). The 'pivotal positions' are those which have the differentiated capability to contribute to organisational outcomes 
due to the fact that not all employees contribute equally to firms' value addition. Top performers contribute more to organisational outcomes than low performing employees (Heinen \& O'Neill 2004). Furthermore, because 'pivotal positions' also have greater impacts on the competitive advantage of firms, they need to be identified and filled with star performers (Huselid, Beatty \& Becker 2005; Mellahi \& Collings 2010). Thus, the development of appropriate human resource structures within organisations ensures that pivotal positions are adequately staffed with the right talent to ensure a sustainable talent pool in the organisation.

The literature which conceptualises talent management has evolved considerably over the last few years. In its developmental stage, talent management, as a concept, used to refer to the management of talented people by focusing on high-performing employees (Michaels, Handfield-Jones \& Axelrod 2001; Smart 1999). More recent developments in the literature on talent management highlight the importance of 'pivotal positions' rather than 'pivotal people' (Collings \& Mellahi 2009) and define strategic talent management as "activities and processes that involve the systematic identification of key positions" which contribute to firm performance, and the development of systems and processes to fill those positions (Collings \& Mellahi 2009). Thus, the primary focus of talent management is in identifying strategic (pivotal) positions within the organisation and in appropriately filling those positions based on well-developed systems and processes for recruitment, retention, remuneration, reward and development of employees. Failure to manage talent effectively has been found to result in the lack of a talent pipeline (Ready \& Conger 2007; Mellahi \& Collings 2010) and a lack of alignment between talent and business strategies (Gutridge, Komm \& Lawson 2006), both of which can adversely impact organisational outcomes. It should also be noted that excessive focus on star performers, which over-values individual performance over group performance, 
runs the risk of encouraging a work place culture which discourages internal collaboration and teamwork (Mellahi \& Collings 2010).

For the purposes of this research, we refer to talent management as the deliberate and organised efforts by firms to optimally select, develop, deploy and retain competent and committed knowledge employees for key positions which bear significant influences on the overall performance of the organisation. Thus, the strategic and deliberate approaches to the identification, selection, recruitment, retention and deployment of staff in an optimal way to influence the overall performance of the organisation are what differentiate talent management from traditional HR functions. The strategic importance of talent management functions in many organisations is evidenced by the greater involvement of top management teams in talent management initiatives rather than leaving them to the HR divisions of the organisation. Strategic talent management is of particular importance for knowledge workers in India's OSPs given the paradox of 'scarcity in abundance' that Indian OSPs face due to the low employability of Indian graduates - varying between $10-25 \%$ only of all graduates (Farrell, Kaka \& Sturze 2005) and the high annual attrition rates approaching 50\% (Kumar \& Puranam 2008). Additionally, India, like many developing countries, also faces the additional challenges of retaining its best talent in an increasingly global market place, where professionals who are mobile are usually attracted by higher wages, and better work and lifestyle conditions in advanced industrialised countries (Mäkelä, Björkman \& Ehrnrooth 2010). Thus, having systematic and rigorous systems to sustain a pool of key employees is essential in ensuring sustained competitive advantage (Axelrod et al. 2002; Huselid et al. 2005). Whelan (2011) argues that talent management is important, even during the global economic downturn when it is critical to identify and retain key talent while planning downsizing. Firms that are able to sustain a pool of talent are more likely to perform well in 
the long run compared to other firms (Vance \& Vaiman 2008). It is particularly important for knowledge intensive organisations, such as OSPs, to ensure that they have talented staff in key positions because their success depends on their ability to acquire and exploit knowledge. And, given the growing importance of external sources of knowledge, particularly tacit knowledge, having talented employees with industry contacts and strong social networks can be of benefit to an organisation. Given the dynamic competitive environment within which Indian OSPs operate and the current global shortage of skilled IT professionals, talent management of knowledge workers is of strategic importance (Beechler \& Woodward 2009; Collings \& Mellahi 2009; Scullion, Collings \& Caligiuri 2010; Tymon et al. 2010).

This paper posits that talent management mediates the effects of external knowledge on the performance of offshore service providers in India. The relationships between a firm's external knowledge (EK), talent management (TM) and its performance are shown in Figure 1. EK has both direct and indirect effects on performance - the indirect effects of EK are captured through the mediating role of TM in enhancing the overall effects of EK on performance. The relationship between EK and TM is discussed next.

\section{**Insert Figure 1 here ** $^{*}$}

\section{External knowledge (EK)}

A firm's capability to create, apply and manage knowledge is critical to its competitiveness (Coff 2003; Grant 1996; Madhok \& Phene 2001; Nonaka \& Toyama 2005). Knowledge management has been found to positively associate with organisational effectiveness (Gold, Malhotra \& Segars 2001); innovation and better performance (Darroch 2005) and a firm's competitiveness (Bogner \& Bansal 2007; Liu, Chen \& Tsai 2004; Marqués and Simón 2006; Tanriverdi 2005). Knowledge acquisition is an integral part of the knowledge management 
process. Knowledge can be acquired from internal and external sources and structured through competitive systems and processes embedded in the organisation. Internal sources of knowledge include intelligence teams, research departments and knowledge systems; while external sources of knowledge can include external research and development bodies such as academic institutions, industry associations and consulting firms. Although the integration of external sources and internal sources of knowledge has been found to lead to better firm performance (Choi, Poon \& Davis 2008), research specific to the effects of external sources of knowledge on firms' performance remains underdeveloped. To date, most research on the contribution of knowledge to firm performance has focused either implicitly or explicitly on internal sources of knowledge, while the role of external sources of knowledge has either been assumed to be similar to that of internal sources of knowledge or has simply been overlooked. Increasingly, firms are relying on external knowledge because not all firms are self-sustained in their knowledge requirements (Allen 1977). Firms that acquire and exploit external sources of knowledge are likely to be more innovative and perform better by being able to operate outside of their knowledge frontier (Cohen \& Levinthal 1990; Whelan, Collings \& Donnellan 2010).

This study fills the research gap on external knowledge by focusing explicitly on external sources of tacit knowledge (EK) as a source of competitive advantage. Of the few studies on external sources of knowledge, there is clear evidence that EK is relevant in improving the performance of firms for innovative products (Jordan \& Segelod 2006), and for knowledgeintensive firms in uncertain and dynamic business environments (Jordan \& Segelod 2006; Powell 1998). As firms are not normally self-sufficient in providing value to their clients, close collaboration with outside knowledge producing agencies allows firms to tap into a broader tacit knowledge base than what is available internally (Desouza, Awazu \& 
Jasimuddin 2005), thereby allowing firms access to knowledge which would otherwise not be available. Access to a broader knowledge pool from external sources, particularly for tacit type knowledge, contributes positively to organisational creativity and problem solving (Soo, Devinney \& Midgley 2007).

The context within which OSPs in the IT sector operate can be described as one where firms face short product life-cycles as a result of a rapidly changing technological environment and changing client needs and expectations (Tarique \& Schuler 2010). In such an environment, firms have to be creative and innovative in order to offer cost effective and innovative solutions to their clients. Firms enhance their creativity and innovation by complementing their internal knowledge with external knowledge from sources such as universities, trade associations and consulting agencies (Andersson \& Ejermo 2005; Fey \& Birkinshaw 2005; Segelod \& Jordan 2004). For example, partnering with universities has been found to significantly improve the performance of R\&D firms (Andersson \& Ejermo 2005; Fey \& Birkinshaw 2005). Similarly, leveraging knowledge from private consultants has been found to be important for firms engaged in software development projects (Segelod \& Jordan 2004). In the context of IT service providers from developing countries, industry associations often play a critical role in filling the institutional void left by the government, particularly in creating the necessary environment within and among firms for knowledge sharing and interfirm collaboration which is critical for firm performance. For example, the main industry association for OSPs in India, the National Association of Software and Services Companies (NASSCOM), plays a pivotal role in setting the overall strategic direction of the sector, providing market intelligence to its members and coordinating the sector's overall activities, including the opportunity to network. The opportunity to network within the industry and with external agencies allows firms to supplement internal knowledge with valuable external 
knowledge, thereby augmenting the available intangible pool of resources. The above discussion leads to the following hypotheses:

Hypothesis 1: External tacit knowledge contributes positively to the performance of service providers.

\section{Talent management (TM)}

The availability of a skilled workforce is a critical element of the competitiveness of firms in general (Bartlett \& Ghoshal 2002). In the case of OSPs, the scarcity of skilled IT professionals has been identified as a major constraint for their growth (Farrell \& Grant 2005; Schuler, Jackson \& Tarique 2010), and the availability of skilled human resources has been identified as a key factor among firms in advanced industrialised countries when deciding on an offshore outsourcing location (Graf \& Mudambi 2005; Lewin, Massini \& Peeters 2009). As the 'global race for talent' (Lewin et al. 2009) and 'the war for talent' (McKinsey 2001) intensify due to the shortage of skilled IT professionals, the performance of technology and knowledge-intensive, people-based firms such as OSPs, is being increasingly linked to the effectiveness with which they manage their talent pool (Ghebregiorgis \& Karsten 2007;

Guest 1997; Harris \& Ogbonna 2001; Kaya 2006). A firm's talent management embodies its deliberate activities to optimally recruit, retain, train, develop and deploy highly-skilled people in strategically identified positions in the organisation. Such positions can be at any level in the organisation as long as they are critically linked to organisational performance (Vance \& Vaiman 2008). Thus, the critical elements of talent management lie in the firm's deliberate strategy to identify key positions which directly impact on its performance and to strategically recruit, develop and retain talented employees in those positions. It is well established in the literature that recruitment, training and development (Lam \& White 1998); selection and development (Hatch \& Dyer 2004); training and development (Luoma 2000; 
Priyadarshini \& Venkatapathy 2005; Stavrou, Charalambous \& Spiliotis 2007), and deployment (Kor \& Leblebici 2005), have positive effects on firm performance. Firms which focus on strategic talent management are likely to have lower attrition rates, lower absenteeism and a more competent workforce, all of which also contribute positively to performance (see Bethke-Langenegger, Mahler \& Staffelbach 2011; Ernst \& Young 2010). The retention of highly-skilled professionals who hold industry-specific tacit knowledge is particularly critical for knowledge-based firms because of the ease with which employees may walk away to competitors taking their knowledge with them. The rapid pace of change in the IT services industry implies that in order to be consistently ahead of competitors, employees need to be continuously up-skilled, thereby highlighting the importance of effective training and development programs. People are a critical core competence and are considered as the most valuable corporate asset (Prahalad \& Hamel 1990, 90), and managing such assets strategically can enhance a firm's competitiveness. Therefore, we hypothesise that talent management practices contribute directly to the performance of OSPs.

Hypothesis 2: Talent management contributes positively to the performance of OSPs.

\section{Mediating effects of talent management}

Although it is intuitive that a strong link should exist between the TM and the knowledge management (KM) literature (Vance \& Vaiman 2008) in relation to the performance of knowledge-intensive organisations in particular, so far there is a lack of research on the interaction between TM and KM and its impact on organisational outcomes (Vance \& Vaiman 2008; Whelan \& Carcary 2011; Whelan et al. 2010). Until recently the KM literature and the HRM literature have so far considered the effects of knowledge and the role of people on firm performance somewhat independently. For example, Whelan and Carcary (2011) find that the challenges of identifying key knowledge workers and the enhancement of knowledge 
creation, sharing, development and retention capabilities can be addressed by applying TM principles.

The literature on how EK is actually transformed into better performance for firms also remains underdeveloped. In this paper it is argued that knowledge can only be transformed into superior performance by having talented staff who can identify, assess and utilise external tacit knowledge in ways which benefit the organisation. A competent workforce is also more likely to seek out knowledge from external sources through employee networks, critically evaluate the relevance of such knowledge for the organisation and utilise it appropriately to benefit the organisation (Afiouni 2007). EK from universities, consulting companies, government agencies and trade associations allows firms to have a better understanding of their business environment, customer needs and the very work force needed to remain competitive. Thus, EK can have both direct and indirect effects on the performance of firms because such knowledge can also improve a firm's talent management and its talent pool. In other words, TM can have a mediating effect on the relationship between EK and firm performance. The mediation effect helps explain 'why' a relationship between predictor (knowledge) and criterion (performance) variables exists (Hair, Black, Babin \& Anderson 2010). In the present case, TM is the mechanism through which EK is able to influence the dependent variable - performance. Hence, the following hypothesis:

Hypothesis 3: Talent management mediates the relationship between external knowledge and the performance of offshore IT service providers. 


\section{Method}

In order to test the direct and mediation effects between external knowledge, talent management and performance of OSPs in India, we follow an approach similar to Baron and Kenny (1986) by specifying and estimating the following basic relationships:

$$
\begin{aligned}
& \operatorname{PERF}_{i}=\alpha_{i}+\beta_{1} E K_{i}+\beta 2 X_{i}+\varepsilon i \\
& \operatorname{PERF}_{i}=\alpha_{i}+\beta_{1} E K_{i}+\beta 2 X_{i}+\beta_{3} T M_{i}+\varepsilon i
\end{aligned}
$$

Where $P E R F_{i} \quad$ is a measure of the performance of firm $i$;

$$
\begin{array}{ll}
E K_{i} & \text { is a measure of external sources of knowledge of firm } i ; \\
T M_{i} & \text { is a measure for talent management practices of firm } i \\
X_{i} & \text { is a vector of control variables influencing the performance of firm } i \\
\beta_{i} & \text { are regression coefficients to be estimated; } \\
\alpha_{i} \text { and } \varepsilon_{i} & \text { denote the intercept and error terms, respectively. }
\end{array}
$$

Equation 1 represents the restricted model which tests the direct effects of EK on PERF $\left(\mathrm{H}_{1}\right)$. In order to test the mediating effect of TM, the specification of equation 1 is expanded to include the mediating variable TM, as specified in equation 2. For TM to have a mediation effect, the following five conditions must be satisfied (Baron \& Kenny 1986, 1177):

1. The independent variable (EK) and the mediator (TM) must be significantly correlated.

2. The independent variable (EK) must affect the mediator (TM) in regressing the mediator on the independent variable.

3. The independent variable (EK) must affect the dependent variable (PERF) in regressing the dependent variable on the independent variable (eq.1).

4. The mediator (TM) must affect the dependent variable (PERF) in regressing the dependent variable on both the independent variable and on the mediator (eq. 2).

5. The effect of the independent variable (EK) on the dependent variable (PERF) must be less in 4 than 3 . 


\section{Sample and data sources}

Equations 1 and 2 above are estimated using data from an industry-wide survey of OSPs in India. A web based questionnaire was developed, pilot tested and administered to a population of 842 OSPs, all members of NASSCOM, India's main trade association of IT service providers, in early 2008. The questionnaire was addressed to a senior executive or the next best person with strategic expertise and familiarity of all aspects of the business. In order to ensure a satisfactory response rate, the questionnaire was endorsed and administered by NASSCOM and two email reminders were sent to participants about the survey and the importance of its timely completion. A total of 79 responses were received by the due date, of which 68 completed responses were retained for the purposes of analysis. Although the response rate $(8.08 \%)$ appears to be low compared to response rates from English speaking industrialised countries, it compares favourably with typical response rates in Asian countries. Low response rates (as low as $<1 \%$ ) in Asian countries are not unusual (Roy \& Berger 2005) and in India in particular, firms are known to be reluctant to disclose company information to third parties for fear of such information being utilised for other purposes which may impact adversely on the company.

An analysis of the sample characteristics (Table 1) indicates that the sample is fairly representative of the population for the age of companies and ownership structure. However, the sample is somewhat underrepresented by small firms (i.e., according to industry standards, firms with fewer than 200 employees and revenues of less than 500 million rupees). By implication, the sample is overrepresented by large firms when compared to the industry. 


\section{Measures}

The data used for this study are part of a large-scale research project on the competitiveness of offshore service providers in India. The survey questionnaire used for the project contained a number of other measurements in addition to those used in this paper. In order to address the main focus of this paper which is on the relationship between external sources of knowledge, talent management practices and firm performance, we developed measures for external knowledge, talent management and performance specific to OSPs, as follows:

\section{Firm performance (PERF)}

The choice of appropriate performance measures is guided largely by the extensive literature on firm performance as well as the industry context under consideration. A variety of objective and subjective measures have been used to evaluate firm performance in the export sector (Aaby \& Slater 1989), including economic measures such as export sales, export growth, profit from exports, and export as a percentage of total sales at the firm level (Cavusgil \& Zou 1994; Madsen 1989). To the extent that OSPs compete domestically as well as in export markets (Kraemer \& Dedrick 2000), this study uses several measures of overall performance rather than focusing narrowly on export performance alone. Because performance is also a relative measure (relative to the industry or sector) and relies primarily on comparison (Buckley, Pass \& Prescott 1988), this study uses perceived growth or change or relative measures rather than absolute static measures to capture the performance of OSPs. Perceptual measures have been used extensively in prior research (Leonidou, Katsikeas \& Samiee 2002) and have been found to be equivalent to, and positively correlated with, actual measures (Wall, Michie, Patterson et al. 2004). 
This research uses four perceptual measures of firm performance, namely, one financial measure, total revenue growth (TRG), and three non-financial measures, client base expansion $(\mathrm{CBE})$, client base retention $(\mathrm{CBR})$ and overall business growth $(\mathrm{OBG})$ relative to the industry average over the previous two years. TRG and OBG have been widely used in the literature (Cho, Ozment \& Sink 2008; Coltman, Devinney \& Midgley 2011). CBE and CBR have also been used in previous research specific to customer relationship management (Coltman, Devinney \& Midgley 2011). The use of CBE and CBR is based on the fact that a unique feature of OSPs is that they are highly dependent on repeat business from major clients. According to NASSCOM (2009), existing customers account for more than $90 \%$ of revenues among the top 20 OSPs. Thus, the ability of OSPs to retain, or better still expand their client base, is a critical indicator of performance. The use of financial and non-financial perceptual measures of performance provides a broader understanding of the overall performance of OSPs. Client base expansion (CBE) and client base retention (CBR) capture the performance of OSPs in terms of their business expansion, as well as reflecting the reputation of the company among its peers. Thus, the ability of OSPs to retain, or better still expand their client base is a critical indicator of performance. Respondents were asked to rate the performance of their firms relative to the industry, for each of the four performance measures above, on a 3-point Likert scale, where $1=$ below industry average, $2=$ same as industry, and $3=$ above industry average.

\section{External knowledge (EK)}

EK refers to the extent to which firms seek out and utilise knowledge from external bodies such as trade agencies, universities, consulting firms and other knowledge networks. Drawing from previous research (Andersson \& Ejermo 2005; Fey \& Birkinshaw 2005; Jordan \& Segelod 2006), respondents were asked to rate the extent to which OSPs utilise external sources of knowledge based on a Likert-type five-point scale anchored at both ends with $1=$ never, $\ldots 3=$ often $\ldots 5=$ all the time. Four items were used to measure external knowledge 
which, together, captured the extent to which OSPs use different sources of external knowledge, such as:

1. NASSCOM as a source of business intelligence

2. Collaboration with universities for knowledge acquisition

3. Market intelligence from private consultants/commercial agencies

4. Network with external stakeholders (clients, suppliers, contractors, etc.) to acquire knowledge

\section{Talent management (TM)}

Talent management is measured based on a number of items related to the firm's deliberate practices in strategically managing its talent pool. We draw from previous studies (Hatch \& Dyer 2004; Kor \& Leblebici 2005; Lam \& White 1998; Luoma 2000; Priyadarshini \& Venkatapathy 2005; Stavrou et al. 2007) in formulating a number of TM items to capture various TM practices within the organisation. Since the focus of the study is on performance and the fact that OSPs compete with each other for talented employees because of the limited talent pool, respondents were asked to rate TM practices pertaining to the identification of talent gaps, selection, recruitment, retention, training and rewarding of talented employees, relative to the industry standards, on a 5-point Likert-type scale anchored at both ends, where $1=$ substantially below industry practices, $\ldots 3=$ about the same as the industry, $\ldots 5=$ substantially above industry practices. The six items used to capture strategic TM practices in OSPs included:

1. Identification and assessment of talent gaps/positions in the company

2. Selection and recruitment of talented staff

3. In-house programs for developing and nurturing talented employees for the company 
4. Provision of financial performance incentives to reward talented staff

5. Company's budget allocated specifically to talent management as $\%$ of total budget

6. Company's overall talent management effectiveness

\section{Control variables}

Following previous research on firm performance, a number of control variables were also included for age, size, ownership and the type of IT services provided by the firm. The control variables are defined as follows: $\mathrm{AGE}=1$, for firms older than 10 years; 0 otherwise; SIZE $=1$, for small firms (revenue less than INR 500 million); 0 otherwise; OWN refers to the ownership structure of service providers, defined as 1 for Indian owned firms, and 0 otherwise; and TYP is used to distinguish between three types of IT services provided by OSPs; namely, IT system services (ITSS), business process services (BPO) and firms providing both BPO and ITSS. With 3 types of firms, two dummy variables were used as follows: TYP1 = 1 for ITSS; 0 otherwise; TYP2 = 1 for BPO; 0 otherwise.

\section{Model estimation and results}

The hypotheses presented in this paper were tested using the regression analysis approach, as recommended by Baron and Kenny (1986). The first step includes undertaking an exploratory factor analysis (EFA) with varimax rotation, using a principal components extraction method to develop operational constructs for each of the two variables of interest, namely, EK and TM. The summary of the EFA results is presented in Table 2. All the factor constructs meet the reliability, convergent validity and unidimensionality criteria. None of the alpha values is less than 0.70 , and they vary between 0.83 and 0.91 . All item-to-total correlations and factor loadings are above 0.50 . 
Since we collected information on both the predictor and criterion variables from the same respondents, the potential threat of common method variance is also explored (Podsakoff, MacKenzie \& Lee 2003). Different formats of scales on predictor and criterion variables are used in the questionnaire, and Harman's single-factor test produced 3 factors satisfying the factors. Therefore, we assume that common method variance is not a major threat to our findings. Although Harman's single-factor test has been widely used in past research, it does not provide robust evidence for the lack of common method variance (Podsakoff et al., 2003); hence, we acknowledge that common method variance is a limitation of the study.

Because of the categorical and ordinal nature of the dependent variables (CBE, CBR, TRG, OBG), ordinal logistic regression techniques available in Statistical Analysis System (SAS) are used for estimation purposes to obtain the maximum likelihood estimates of the parameters of equations (1) and (2). Logit type models [i.e. Logit $(\mathrm{P})=\log (\mathrm{P} / 1-\mathrm{P})=\alpha+$ $\beta^{\prime} \mathrm{X}$; where $\mathrm{P}=\operatorname{Pr}(\mathrm{Y}=1 \mid \mathrm{X})$ is the response probability to be modelled and $\alpha$ is the intercept] assume the effects of the independent variables (X) to be linear in the logarithm of the odds ratio of the dependent variable. The estimated $\beta$ coefficients show the effect of a change in the explanatory variables $(\mathrm{X})$ on the logarithm of the odds that a particular level of performance will be achieved. A positive $\beta$ coefficient indicates that an increase in the dependent variable leads to a positive change in the independent variable which, in this case, corresponds to a higher level of performance.

Four performance models are estimated, namely, total revenue growth (TRG), client base expansion (CBE), client base retention (CBR), and overall business growth (OBG). The coefficient estimates, likelihood ratios and Wald Chi-square statistics of the four models suggest that all the models perform well (see Table 4). There is high association between the 
predicted and actual probabilities in all four models, as evidenced by the concordant values of all four models, which range between $68 \%$ and $82 \%$. All four models have acceptable $R^{2}$ values for cross-section data and also satisfy the model convergence $(\mathrm{GCONV}=1 \mathrm{E}-8)$ and the proportional odds assumption criteria. Interestingly, none of the control variables is significant; suggesting that firm size, type and age do not significantly affect performance. The correlation table and regression results are presented in Table 3, Table 4 and Table 5, respectively.

\section{**Insert Table 3, Table 4, and Table 5 here**}

The estimated Pearson correlation coefficient for EK and TM (see Table 3) is 0.44 and significant at 1 percent level which satisfies the first condition for mediation effects. The second condition for mediation is that the independent variable must affect the mediator when regressing the mediator on the independent variable. The results in Tables 4 and 5 show that $\mathrm{TM}=\alpha+0.43 \mathrm{EK}$ with the parameter estimate for EK statistically significant at the 1 percent level. Thus, condition 2 is also satisfied.

The restricted models (equation 1) are estimated for the four performance measures to verify condition 3. The results presented in Table 4 and summarised in Table 5 show that in each of the four restricted models the parameter estimate for EK is statistically significant, thereby satisfying condition 3. In other words, EK is found to be positive and highly significant with TRG and OBG, while it is positive and significant with CBE and CBR. The odds ratio point estimates suggest that for every one unit increase in EK, the odds of being in a higher performance category are nearly twice for $\mathrm{CBE}$ and $\mathrm{CBR}$, and about three times for TRG and OBG. This implies that for every unit increase in the use of EK, OSPs can increase their overall performance significantly. 
The full model (equation 2) is estimated for all four performance measures to verify condition 4. Tables 4 and 5 present the parameter estimates for equation 2. The results suggest that TM is positive and highly significant in all four full models, namely, CBE, CBR, TRG and OBG, thereby strongly supporting $\left(\mathrm{H}_{2}\right)$ and satisfying condition 4 . The odds ratio point estimates imply that for every one unit increase in TM, the odds for firm performance to improve are about 3 to 4 times.

EK has both direct and indirect (through TM) positive and significant effects on the performance of OSPs. The parameter estimates from equation 2 support both $\mathrm{H}_{1}$ and $\mathrm{H}_{2}$. A comparison of the parameter in the restricted and full models shows that the absolute values of the parameter estimates for EK in all four full models are smaller than the parameter estimates in the restricted models, which is a necessary condition for mediation. Hence, condition 5 is satisfied for all four models. The overall results summarised in Table 4 also suggest that TM fully mediates the effects of EK on CBE and CBR, the two client-based related performance measures, while only having partial mediation effects on total revenue growth (TRG) and overall business growth (OBG).

\section{Discussion and conclusions}

The main objective of this study was to investigate the role of talent management on the performance of knowledge-intensive, people-based organisations where knowledge and human capital constitute the two main firm-specific resources. Although the effects of knowledge and human capital are well established in the management literature, we identify three main gaps in relation to knowledge-intensive, people-based firms in particular. First, the roles of external sources of knowledge and strategic talent management have been overlooked in the literature; second, the interplay between external knowledge and talent 
management is under researched and, third, research on the behaviour and performance of OSPs, in India in particular, is still in its infancy despite the phenomenal growth experienced by this industry over the recent past. For our investigation, we draw from the experience of a sample of OSPs in India. Indian OSPs play a dominant role in the global offshoring market for IT services, and India has also established itself as a preferred supplier of offshoring IT services.

The findings confirm that both external knowledge and talent management practices contribute positively to the performance of OSPs and that talent management mediates the effects of external knowledge on performance. The results also support previous findings of the positive effects of external sources of knowledge and strategic human resource management practices on firm performance (Jordan \& Segelod 2006; Powell 1998; Stavrou et al. 2007). The study contributes to the knowledge management and talent management literature by explicitly investigating the interplay between external knowledge and talent management practices of OSPs and contributes to the call for greater fusion of the TM and KM literature (Vance \& Vaiman 2008; Whelan \& Carcary 2011). Furthermore, in order to gain a broad understanding of how talent management and external knowledge impact on OSPs, we use four measures of performance, including two client-related measures, one financial measure and a fourth overall performance measure. Interestingly, although talent management is found to have a mediation effect on the relationship between external knowledge and performance, the results show that there is complete mediation for the two client-related performance measures (CBR and $\mathrm{CBE})$, while strong partial mediation is found for the other two performance measures (TRG and OBG). Complete mediation implies that external knowledge by itself does not impact the ability of OSPs to retain their clients (CBR) and to grow their client base (CBE). By comparison, talent management partially mediates 
the effects of external knowledge (EK) on total revenue growth (TRG) and overall business growth (OBG) of OSPs, implying that talent management provides the mechanism through which external sources of knowledge are exploited for the benefit of the organisation.

The knowledge management literature (Andersson \& Ejermo 2005; Fey \& Birkinshaw 2005; Jordan \& Segelod 2006; Segelod \& Jordan 2004; Soo et al. 2007) highlights the role of external knowledge in improving firm performance, particularly for knowledge-based firms. Collaboration with external sources of knowledge such as universities, trade associations and consulting companies helps firms to complement their internal knowledge base by accessing knowledge which otherwise would not be available (Desouza et al. 2005). Such collaboration also has the potential to have positive effects on firm creativity and innovation (Soo et al. 2007). Collaboration with universities, for example, has been found to result in superior performance for knowledge intensive firms (Andersson \& Ejerno 2005; Segelod \& Jordan 2004) in a number of ways including the provision of professional development opportunities, sharing of research facilities, and assistance in solving business problems. Similarly, trade bodies and consulting firms are valuable sources of business intelligence and provide a platform for OSPs to further extend their networks, particularly in international markets. Professional and trade associations are often more effective than the government under certain conditions in developing economies and can influence the behaviour of their members in shaping the industry landscape (Kshetri \& Dholakia 2009). This is particularly the case in the context of firms in developing countries where 'institutional voids' are often filled by formal and informal networks within the industry (Peng et al. 2008). Networks also serve as valuable information conduits in the absence of well-developed support infrastructure for creating and disseminating knowledge similar to those which exist in industrialised countries. 
The findings also provide strong support for the original contention of the paper that talent management mediates the effects of knowledge on performance by acting as a mechanism through which knowledge is transformed into performance. The talent management literature argues that the deliberate and organised efforts by firms to identify, attract, select, develop, deploy and retain a pool of talented employees contribute positively to firm performance (Hatch \& Dyer 2004; Lam \& White 1998; Panayotopoulou \& Papalexandris 2004; Schuler et al. 2010; Tymon et al. 2010). The findings in this research confirm the positive contribution of talent management to the performance of knowledge-intensive, people-based firms such as the OSPs in India. The focus on OSPs in India provides insights for other developing countries, in general, on the challenges of managing their talent pools in an increasingly global market demand for professional and skilled workers. The retention of employees with tacit knowledge is likely to become a major source of competitive advantage for firms because such employees are more likely to transform external sources of knowledge into superior performance for the organisation. OSPs in developing countries are particularly vulnerable to the looming skill shortage in the IT sector because of the ease with which skilled IT professionals from developing countries can move to higher paid jobs in advanced industrialised countries. As many of the emerging OSPs in the IT sector are located in developing economies in Asia, such as the Philippines, Malaysia, Indonesia and China, their competitiveness in general can also benefit by embracing talent management within the organisation.

There are three important implications of the main findings. The findings from this study highlight the critical role that talent management has for the performance of OSPs. First, it is clear that one of the challenges facing OSPs in general and OSPs in India in particular, is the 
recruitment and retention of talented employees. In this context, partnering with universities may help alleviate the shortage of skilled IT professionals because universities may assist OSPs with training and development programs which can improve talent retention as well as developing the next generation of talent for the organisation. Knowledge from universities and trade associations may also be helpful for OSPs in their recruitment campaigns and in promoting the organisation as an exciting place to work in order to attract talented employees. Second, knowledge from external bodies has also been found to be a critical source of competitiveness. Thus, working closely with external organisations such as trade associations, consulting firms and government bodies can help OSPs grow their client base and their overall performance. For example, NASSCOM, which acts as a link between its members, the government and the outside world, can be a valuable source of market intelligence from which OSPs can benefit. Third, given the global shortage of skilled IT professionals, OSPs would benefit by investing in their own training and development programs to grow their own talent, as well as ensuring the overall welfare of their employees in order to improve their retention rates. Focus on these areas should result in improved competitiveness.

As with all research, the findings in this paper should be interpreted with caution because it suffers from several limitations. First, we readily acknowledge that the small sample size on which the analysis is based is an inherent limitation of the study. While every effort was made to ensure a better response rate from our survey, the reality is that collecting data in India is challenging under the best of conditions. Care should be taken, therefore, in interpreting and generalising the findings. Second, the study focuses on Indian OSPs only and caution should be exercised not to generalise the findings to OSPs from other countries. In order to address these two limitations, it may be worthwhile extending this research to other 
economies and contrasting the effects of talent management from different institutional contexts based on a large-scale survey. A third limitation is related to the conceptualisation of talent management. To the extent that the talent management literature itself is in its infancy, there is scope for further research in conceptualising talent management to be further developed to unambiguously capture the meaning of talent management and to clearly differentiate it from strategic human resource management. A fourth limitation of the study relates to the use of subjective and perceptual measures of performance rather than objective financial measures. Although perceived measures have been found to be reliable and highly correlated with objective measures (Wall, Michie, Patterson et al. 2004), the use of objective performance measures have the advantage of providing a quantifiable assessment of the magnitude of the effects of how changes in external sources of knowledge and strategic talent management practices can contribute to the bottom line of the organisation.

This study provides empirical evidence that talent management has a mediating role on the effects that external knowledge has on performance. This finding enriches our understanding of the behaviour and performance of service firms in general, and knowledge-intensive firms in particular. It would be valuable for future research to extend the enquiry to a broader sample of firms from different sectors, including the manufacturing sector, to gain further insights into the effects of talent management and external knowledge on organisational performance, particularly within a cross-country framework. 


\section{References}

Aaby N-E and SF Slater (1989) Management influences on export performance: A review of the empirical literature 1978-88. International Marketing Review 6(4), 7-26.

Afiouni F (2007) Human resource management and knowledge management: A road map toward improving organizational performance. Journal of American Academy of Business 11(2), 124-130.

Allen TJ (1977) Managing the flow of technology. MIT Press, Cambridge, MA.

Andersson M and O Ejermo (2005) How does accessibility to knowledge sources affect the innovativeness of corporations? Evidence from Sweden. The Annals of Regional Science 39(4), 741-765.

Axelrod B, H Handfield-Jones and E Michaels (2002) A new game plan for C players. Harvard Business Review 80(1), 81-88.

Barney JB (1991) Firm resources and sustained competitive advantage. Journal of Management 17(1), 99-120.

Barney JB (2001) Is the resource based 'view' a useful perspective for strategic management research? Yes. Academy of Management Review 26(1), 41-56.

Baron RM and DA Kenny (1986) The moderator-mediator variable distinction in social psychological research: Conceptual, strategic, and statistical considerations. Journal of Personality and Social Psychology 51(6), 1173-1182.

Bartlett CA and S Ghoshal (2002) Building competitive advantage through people. MIT Sloan Management Review 43(2), 34-41.

Becker BE and MA Huselid (2006) Strategic human resources management: Where do we go from here? Journal of Management 32, 898-925.

Beechler S and IC Woodward (2009) The global "war for talent". Journal of International Management 15, 273-285.

Bethke-Langenegger P, P Mahler and B Staffelbach (2011) Effectiveness of talent management strategies. European Journal of International Management 5(5), 524-539.

Bogner WC and P Bansal (2007) Knowledge management as the basis of sustained high performance. Journal of Management Studies 44(1), 165-188.

Boudreau JW and PM Ramstad (2005a) Talentship and the new paradigm for human resource management: From professional practices to strategic talent decision science. Human Resource Planning 28(2), 17-26.

Boudreau JW and PM Ramstad (2005b) Talentship, talent segmentation, and sustainability: A new HR decision science paradigm for a new strategy definition. Human Resource Management 44, 129-136.

Boudreau JW PM and Ramstad (2005c) Where's your pivotal talent? Harvard Business Review 83(4), 23-23.

Boudreau JW and PM Ramstad (2007) Beyond HR: The new science of human capital. Harvard Business School Press, Boston, MA.

Buckley PJ, CL Pass and K Prescott (1988) Measures of international competitiveness: A critical survey. Journal of Marketing Management 4(2), 175-200.

Cavusgil ST and S Zou (1994) Marketing strategy-performance relationship: An investigation of the empirical link in export market ventures. Journal of Marketing 58(1), 1-21.

Chadee D and R Raman (2009) International outsourcing of information technology services: Review and future directions. International Marketing Review 26(4/5), 411-438.

Chadee D, R Raman and S Michailova (2011) Sources of competitiveness of offshore IT service providers in India: Towards a conceptual model. Competition \& Change 15(3), 196-220. 
Cheese P, RJ Thomas and E Craig (2008) The talent power organization: Strategies for globalization, talent management and high performance. Kogam Press, London and Philadelphia.

Cho JJ-K, J Ozment and H Sink (2008) Logistics capability, logistics outsourcing and firm performance in an e-commerce market. International Journal of Physical Distribution \& Logistics Management 38(5), 336-359.

Choi B, SK Poon and JG Davis (2008) Effects of knowledge management strategy on organizational performance: A complementarity theory-based approach. Omega 36 (2), 235-251.

Coff RW (2003) The emergent knowledge-based theory of competitive advantage: An evolutionary approach to integrating economics and management. Managerial and Decision Economics 24(4), 245-251.

Cohen W and D Levinthal (1990) Absorptive capacity: A new perspective on learning and innovation. Administration Science Quarterly 35, 128-152.

Collings DG and K Mellahi (2009) Strategic talent management: A review and research agenda. Human Resource Management Review 19(4), 304-313.

Collings DG, H Scullion and V Vaiman (2011) European perspectives on talent management. European Journal of International Management 5(5), 453-462.

Coltman T, T Devinney and D Midgley (2011) Customer relationship management and firm performance. Journal of Information Technology 26, 205-219.

Darroch J (2005) Knowledge management, innovation and firm performance. Journal of Knowledge Management 9(3), 101-115.

Deblina (2010) Industry growth slips to $11.5 \%$. India Business Review, http://www.businessreviewindia.in/news/india-industrial-news/industry-growth-slips$\underline{115}$.

Desouza K, Y Awazu and SM Jasimuddin (2005) Utilizing external sources of knowledge. Knowledge Management Review 8(1), 16-19.

EITO (2006) ICT Markets. European Information Technology Observatory http://www.eito.com/download/EITO\%202006\%20\%20ICT\%20market\%20March\%202006.pdf.

Ernst and Young (2010) Managing today's global workforce: evaluating talent management to improve business. Ernst and Young, London.

Farrell D and AJ Grant (2005) China's looming talent shortage. The McKinsey Quarterly (4), 70.

Farrell D, N Kaka and S Sturze (2005) Ensuring India's offshore future. The McKinsey Quarterly Special Edition 75-83.

Fey CF and J Birkinshaw (2005) External sources of knowledge, governance mode, and R\&D performance. Journal of Management 31(4), 597-621.

Gartner. Forecast: IT Services, Worldwide 2003-2010 2006 [cited 28-08-2008. Available from http://gartner.lbr.auckland.ac.nz.ezproxy.auckland.ac.nz/.

Ghebregiorgis F L and Karsten (2007) Human resource management and performance in a developing country: The case of Eritrea. International Journal of Human Resource Management 18(2), 321-332.

Gold AH, A Malhotra and AH Segars (2001) Knowledge management: An organizational capabilities perspective. Journal of Management Information Systems 18(1), 185-214.

Graf M and SM Mudambi (2005) The outsourcing of IT-enabled business processes: A conceptual model of the location decision. Journal of International Management 11(2), 253-268.

Grant RM (1996) Toward a knowledge-based theory of the firm. Strategic Management Journal 17 (Winter Special Issue) 109-122. 
Guest DE (1997) Human resource management and performance: A review and research agenda. International Journal of Human Resource Management 8(3), 263-276.

Gutridge M, AB Komm and E Lawson (2006) The people problem in talent management. The McKinsey Quarterly 2, 6-8.

Hair JF, WC Black, BJ Babin and RE Anderson (2010) Multivariate data analysis: A global perspective. Seventh ed. New Jersey: Pearson.

Harris LC and E Ogbonna (2001) Strategic human resource management, market orientation, and organizational performance. Journal of Business Research 51(2), 157-166.

Hatch NW and JH Dyer (2004) Human capital and learning as a source of sustainable competitive advantage. Strategic Management Journal 25(12), 1155-1178.

Heinen JS and C O'Neill (2004) Managing talent to maximise performance. Employment Relations Today, 67-82.

Huselid MA, RW Beatty and BE Becker (2005) A-players or A-positions? The strategic logic of workforce management. Harvard Business Review, December, 110-117.

IDFC (2010) India Infrastructure Report 2009. New Delhi: Oxford University Press.

Jordan G and E Segelod (2006) Software innovativeness: Outcomes on project performance, knowledge enhancement, and external linkages. R\&D Management 36(2), 127-142.

Kaya N (2006) The impact of human resource management practices and corporate entrepreneurship on firm performance: Evidence from Turkish firms. International Journal of Human Resource Management 17(12), 2074-2090.

Kor YY and H Leblebici (2005) How do interdependencies among human-capital deployment, development, and diversification strategies affect firms' financial performance? Strategic Management Journal 26(10), 967-985.

Kraemer KL and J Dedrick (2000) The information technology sector and international competitiveness: A background paper. In International competitiveness of Asian economies: A cross-country study. Bangkok: Asian Development Bank.

Kshetri N and N Dholakia (2009) Professional and trade associations in a nascent and formative sector of a developing economy: A case study of the NASSCOM effect on the Indian offshoring industry. Journal of International Management 15, 225-239.

Kumar N and P Puranam (2008) High wages, attrition compel IT sector to look beyond India. The Economic Times, Mumbai.

Lam LW and LP White (1998) Human resource orientation and corporate performance. Human Resource Development Quarterly 9(4), 351-364.

Leonidou LC, CS Katsikeas and S Samiee (2002) Marketing strategy determinants of export performance: A meta-analysis. Journal of Business Research 55(1), 51-67.

Lewin A, S Massini and C Peeters (2009) Why are companies offshoring innovation? The emerging global race for talent. Journal of International Business Studies 40(6), 901925.

Liu P-L, W-C Chen and C-H Tsai (2004) An empirical study on the correlation between knowledge management capability and competitiveness in Taiwan's industries. Technovation 24(12), 637-644.

Luoma M (2000) Developing people for business success: Capability-driven HRD in practice. Management Decision 38(3), 145-153.

McKinsey (2001) The war for talent. Organization and Leadership Practice, http://autoassembly.mckinsey.com/html/downloads/articles/War_For_Talent.pdf.

McKinsey (2005) Extending India's Leadership of the Global IT and BPO Industries 2005 [cited 30-03-2006. Available from http://www.nasscom.org/download/Mckinsey_study_2005_Executive_summary.pdf. 
Madhok A and A Phene (2001) The co-evolutional advantage: Strategic management theory and the eclectic paradigm. International Journal of the Economics of Business 8(2), 243-256.

Madsen TK (1989) Successful export marketing management: Some empirical evidence. International Marketing Review 6(4), 41.

Mäkelä K, I Björkman and M Ehrnrooth (2010) How do MNCs establish their talent pools? Influences on individuals' likelihood of being labelled as talent. Journal of World Business 45, 134-142.

Marqués DP and FJG Simón (2006) The effect of knowledge management practices on firm performance. Journal of Knowledge Management 10(3), 143-156.

Mellahi K and D Collings (2010) The barriers to effective global talent management: The example of corporate élites in MNEs. Journal of World Business 45, 143-149.

Michaels E, H Handfield-Jones and B Axelrod (2001) The war for talent. Harvard Business School Press, Boston, MA.

Nonaka I (1994) A dynamic theory of organizational knowledge creation. Organization Science 5(1), 14.

Nonaka I and R Toyama (2005) The theory of the knowledge-creating firm: Subjectivity, objectivity and synthesis. Industrial and Corporate Change 14(3), 419-436.

Nasscom (2009) Annual Report 2008-2009. National association of software and service companies, New Delhi.

Nasscom (2010) Annual Report 2009-2010. National association of software and service companies, New Delhi.

Nasscom (2011) The IT-BPO sector in India - strategic review 2011. National Association of Software and Service Companies, New Delhi,OECD. Information Technology Outlook 2006 [cited 28-08-2008. Available from http://fiordiliji.sourceoecd.org.ezproxy.auckland.ac.nz/vl=7286061/cl=69/nw=1/rpsv/ cgi-bin/fulltextew.pl?prpsv=/ij/oecdthemes/99980134/v2006n16/s4/p34.idx.

Panayotopoulou L and N Papalexandris (2004) Examining the link between human resource management orientation and firm performance. Personnel Review 33(5/6), 499-520.

Peng MW, DYL Wang and Y Jiang (2008) An institution-based view of international business strategy: A focus on emerging economies. Journal of International Business Studies 39(5), 920-936.

Podsakoff PM, SB MacKenzie and J-Y Lee (2003) Common method bias in behavioral research: A critical review of the literature and recommended remedies. Journal of Applied Psychology 88(5), 879-903.

Powell WW (1998) Learning from collaboration: Knowledge and networks in the biotechnology and pharmaceutical industries. California Management Review 40(3), 228-240.

Prahalad CK and G Hamel (1990) The core competence of the corporation. Harvard Business Review 68(3), 79-91.

Priyadarshini RRG and R Venkatapathy (2005) Performance and human resource development: A study among various types of banks. South Asian Journal of Management 12(3), 52.

Raman R and D Chadee (2011) A comparative assessment of the information technology services sector in India and China. Journal of Contemporary Asia 41(3), 453-470.

Ready DA and JA Conger (2007) Make your company a talent factory. Harvard Business Review, June, 69-77.

Roy A and PD Berger (2005) E-mail and mixed mode database surveys revisited: Exploratory analyses of factors affecting response rates. Journal of Database Marketing \& Customer Strategy Management 12(2), 153-171. 
Schuler RS, SE Jackson and I Tarique (2010) Global talent management and global talent challenges: Strategic opportunities for IHRM. Journal of World Business doi: 10.1016/j.jwb.2010.10.011.

Scullion H, DG Collings and P Caligiuri (2010) Global talent management. Journal of World Business 45,105-108.

Segelod E and G Jordan (2004) The use and importance of external sources of knowledge in the software development process. R\&D Management 34(3), 239-252.

Shukla A (2010) IT managed services market in India to hit \$US3.8 billion in 2013. TechWorld, http://www.techworld.com.au/article/345074/it_managed_services_market_india_hit us3_8_billion_2013/.

Smart BD (1999) Topgrading: How leading companies win by hiring, coaching, and keeping the best people. Prentice-Hall Press, Paramus, NJ.

Soo CW, TM Devinney and DF Midgley (2007) External knowledge acquisition, creativity and learning in organisational problem solving. International Journal of Technology Management 38(1/2), 137-159.

Stavrou ET, C Charalambous and S Spiliotis (2007) Human resource management and performance: A neural network analysis. European Journal of Operational Research 181(1), 453-467.

Tanriverdi H (2005) Information technology relatedness, knowledge management capability, and performance of multibusiness firms. MIS Quarterly 29(2), 311-334.

Tarique I and RS Schuler (2010) Global talent management: Literature review, integrative framework, and suggestions for future research. Journal of World Business 45, 122 133.

Thite M and B Russell (2010) Work organization, human resource practices and employee retention in Indian call centres. Asia Pacific Journal of Human Resources 48, 356374.

Tymon WG, SA Stumpf and JP Doh (2010) Exploring talent management in India: The neglected role of intrinsic rewards. Journal of World Business 45, 109-121.

UNCTAD (2009) United Nations Conference on Trade and Development: Handbook of Statistics 2009. New York: United Nations Publication.

Vance CM and V Vaiman (2008) Smart talent management: On the powerful amalgamation of talent management and knowledge management. In Smart talent management: Building knowledge assets for competitive advantage, eds V Vaiman and CM Vance. Edward Elgar Publishing, Cheltenham, UK.

Wall TD, J Michie, M Patterson, SJ Wood, M Sheehan, CW Clegg and M West (2004) On the validity of subjective measures of company performance. Personnel Psychology 57(1), 95-118.

Whelan E (2011) It's who you know not what you know: A social network analysis approach to talent management. European Journal of International Management 5(5), 484-500.

Whelan E and M Carcary (2011) Integrating talent and knowledge management: Where are the benefits? Journal of Knowledge Management 15, 675-687.

Whelan E, DG Collings and B Donnellan (2010) Managing talent in knowledge-intensive settings. Journal of Knowledge Management 14, 486-504. 
Figure 1: Conceptual Model

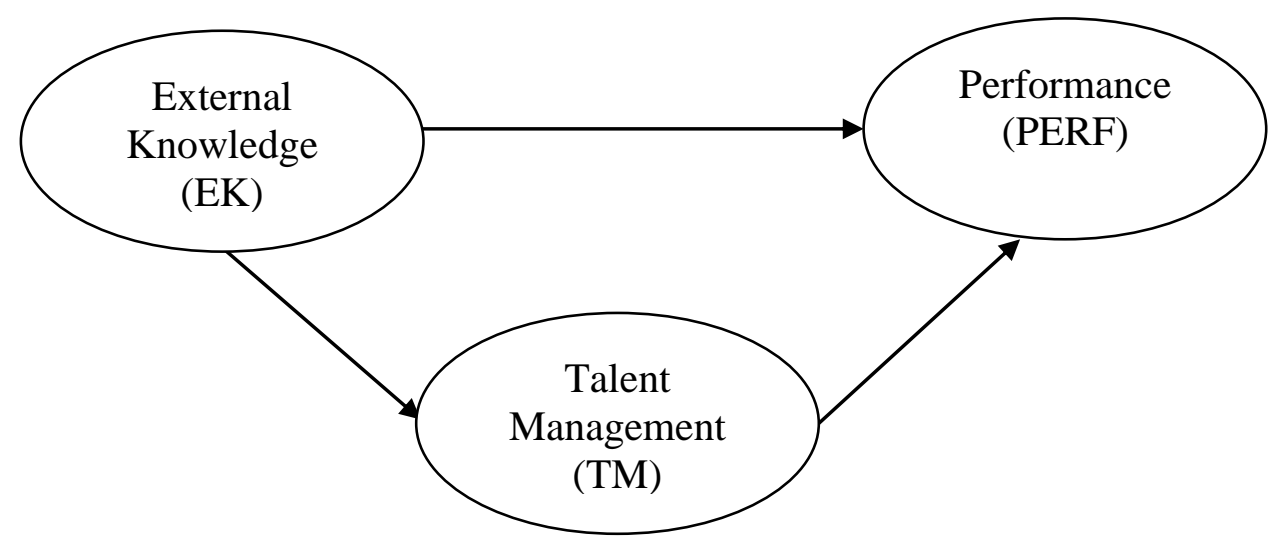


Table 1: Sample Characteristics

\begin{tabular}{|c|c|c|c|}
\hline & $\begin{array}{c}\text { Sample } \\
(\text { Number })\end{array}$ & $\begin{array}{c}\text { Sample } \\
(\%)\end{array}$ & $\begin{array}{c}\text { Industry } \\
(\%)^{*}\end{array}$ \\
\hline $\begin{array}{c}\text { Age (Year of incorporation) (N=68) } \\
\leq 1996\end{array}$ & 29 & 43 & 30 \\
$>1996$ & 39 & 57 & 70 \\
\hline $\begin{array}{c}\text { Turnover (Rupees million, 2006) (N=51) } \\
\leq 500\end{array}$ & 22 & 43 & 85 \\
$>500$ & 29 & 57 & 15 \\
\hline $\begin{array}{c}\text { Number of Employees (2006) (N=61) } \\
\leq 200\end{array}$ & 20 & 33 & 69 \\
$201-1000$ & 23 & 30 & 21 \\
$\geq 1000$ & 53 & 78 & 63 \\
\hline Ownership Type (2006) (N =68) & 15 & 22 & 37 \\
Indian Owned & & & \\
Foreign Owned & & & \\
* NASSCOM (2009) & & & \\
\end{tabular}


Table 2: Operational Measure of the Explanatory Variables

\begin{tabular}{|c|c|c|c|c|c|}
\hline \multirow[b]{2}{*}{$\begin{array}{l}\text { Explanatory Variables/Factors } \\
\qquad(\mathrm{n}=68)\end{array}$} & \multirow[b]{2}{*}{$\begin{array}{c}\text { Reliability } \\
\text { (Cronbach Alpha) }\end{array}$} & \multirow{2}{*}{$\begin{array}{l}\text { Convergent Validity } \\
\text { (Item to total } \\
\text { correlations) }\end{array}$} & \multicolumn{3}{|c|}{ Unidimensionality } \\
\hline & & & $\begin{array}{c}\text { Factor } \\
\text { Loadings }\end{array}$ & $\begin{array}{l}\text { Eigen } \\
\text { Values }\end{array}$ & $\begin{array}{c}\% \text { of } \\
\text { Var. Explained }\end{array}$ \\
\hline $\begin{array}{l}\text { External Knowledge from }(E K) \\
\text { NASSCOM } \\
\text { Universities } \\
\text { Consulting firms } \\
\text { Other networks }\end{array}$ & 0.82 & $\begin{array}{l}0.54 \\
0.70 \\
0.61 \\
0.76 \\
\end{array}$ & $\begin{array}{l}0.60 \\
0.79 \\
0.68 \\
0.83 \\
\end{array}$ & 2.13 & 1.15 \\
\hline $\begin{array}{l}\text { Talent Management }(T M) \\
\text { Talent skill identification } \\
\text { Talent selection and recruitment } \\
\text { Talent development programs } \\
\text { Talent retention } \\
\text { Talent resource allocation } \\
\text { Overall talent program effectiveness }\end{array}$ & 0.88 & $\begin{array}{l}0.74 \\
0.68 \\
0.72 \\
0.59 \\
0.62\end{array}$ & $\begin{array}{l}0.79 \\
0.77 \\
0.78 \\
0.64 \\
0.65\end{array}$ & 3.36 & 1.00 \\
\hline
\end{tabular}


Table 3: Pearson Correlation Coefficients, Means and Standard Deviations $(n=68)$

\begin{tabular}{|c|c|c|c|c|c|c|c|c|c|c|c|c|c|}
\hline & 1 & 2 & 3 & 4 & 5 & 6 & 7 & 8 & 9 & 10 & 11 & Mean & $\begin{array}{c}\text { Standard } \\
\text { Deviation }\end{array}$ \\
\hline 1. EK & 1 & & & & & & & & & & & 0 & 0.95 \\
\hline 2. TM & $0.44 *$ & 1 & & & & & & & & & & 0 & 0.90 \\
\hline 3. Age & $0.31 *$ & $0.27 *$ & 1 & & & & & & & & & 0.4 & 0.49 \\
\hline 4. Size & -0.14 & -0.21 & $-0.45^{*}$ & 1 & & & & & & & & 0.6 & 0.49 \\
\hline 5. OWN & 0.06 & 0.01 & -0.00 & $0.29 * *$ & 1 & & & & & & & 0.8 & 0.42 \\
\hline 6. TYPE1 & 0.03 & -0.34 & -0.04 & $0.29 * *$ & 0.21 & 1 & & & & & & 0.4 & 0.49 \\
\hline 7. TYPE2 & -0.17 & 0.05 & -0.19 & 0.11 & 0.10 & $-0.41 *$ & 1 & & & & & 0.2 & 0.41 \\
\hline 8. $\mathrm{CBE}$ & $0.36^{*}$ & $0.55^{*}$ & $0.40 *$ & $-0.30 *$ & -0.08 & -0.07 & -0.20 & 1 & & & & 2.4 & 0.96 \\
\hline 9. CBR & $0.32 *$ & $0.59 *$ & $0.28 * *$ & $-0.24 * *$ & -0.04 & -0.17 & -0.08 & $0.80^{*}$ & 1 & & & 2.9 & 0.87 \\
\hline 10. TRG & $0.50 *$ & $0.53 *$ & $0.34 *$ & -0.18 & 0.13 & -0.03 & -0.07 & $0.70^{*}$ & $0.75^{*}$ & 1 & & 2.6 & 1.12 \\
\hline 11. OBG & $0.54 *$ & $0.64 *$ & $0.37 *$ & -0.19 & -0.07 & -0.16 & -0.11 & $0.73^{*}$ & $0.75^{*}$ & $0.85^{*}$ & 1 & 2.7 & 1.02 \\
\hline
\end{tabular}


Table 4: Regression Results and Parameter Estimates $(\mathbf{n}=68)$

\begin{tabular}{|c|c|c|c|c|c|c|c|c|c|}
\hline & \multirow[t]{2}{*}{$\mathrm{HRO}$} & \multicolumn{2}{|c|}{$\begin{array}{c}\text { Model } 1 \\
\text { CBE }\end{array}$} & \multicolumn{2}{|c|}{$\begin{array}{c}\text { Model } 2 \\
\text { CBR }\end{array}$} & \multicolumn{2}{|c|}{$\begin{array}{c}\text { Model } 3 \\
\text { TRG }\end{array}$} & \multicolumn{2}{|c|}{$\begin{array}{c}\text { Model } 4 \\
\text { OBG }\end{array}$} \\
\hline & & Restricted & Full & Restricted & Full & Restricted & Full & Restricted & Full \\
\hline Adjusted R-square & 0.28 & 0.28 & 0.45 & 0.18 & 0.40 & 0.29 & 0.41 & 0.37 & 0.52 \\
\hline Likelihood Ratio & & $20.47 *$ & $36.49 *$ & $12.08 * *$ & $31.22 *$ & $21.68 *$ & $32.75^{*}$ & $28.76 *$ & $45.41 *$ \\
\hline Wald Statistics & & $17.78 *$ & $27.85 *$ & $11.01 * *$ & $25.30 *$ & $17.56 *$ & $25.93 *$ & $23.12 *$ & $32.96 *$ \\
\hline Percent Concordant & & 73.4 & 80 & 68.5 & 79.1 & 73 & 76.9 & 75.8 & 81.8 \\
\hline $\mathrm{EK}$ & $0.43 *$ & $0.53 * *$ & 0.17 & $0.55 * *$ & 0.07 & $0.96^{*}$ & $0.67 * *$ & $1.14^{*}$ & $0.83 *$ \\
\hline TM & ---- & ---- & $1.29 *$ & ---- & $1.43^{*}$ & ---- & $1.03 *$ & ---- & $1.33 *$ \\
\hline $\mathrm{AGE}$ & 0.25 & $1.12 * *$ & $0.96 * *$ & 0.41 & 0.27 & 0.69 & 0.64 & 0.97 & 0.81 \\
\hline SIZE & -0.03 & -0.57 & -0.54 & -0.44 & -0.51 & -0.17 & -0.08 & 0.27 & 0.47 \\
\hline OWN & 0.14 & -0.02 & -0.40 & 0.22 & -0.08 & 0.72 & 0.59 & -0.34 & -0.68 \\
\hline TYPE1 & $-0.70 *$ & -0.45 & 0.43 & -0.80 & 0.02 & -0.22 & 0.49 & -0.99 & -0.24 \\
\hline TYPE2 & -0.01 & -0.82 & -0.78 & -0.43 & -0.41 & 0.01 & 0.07 & -0.47 & -0.45 \\
\hline
\end{tabular}

Notes: EK = External Sources of Knowledge, TM = Talent Management, CBE = Client Base Expansion, CBR = Client Base Retention, TRG = Total Revenue Growth, OBG = Overall Business Growth, $*=1 \%$ Level of significance, $* *=5 \%$ Level of significance. 
Table 5: Comparison of Restricted and Full Models: Summary $(n=68)$

\begin{tabular}{|c|c|c|c|c|c|}
\hline \multirow{2}{*}{ Model } & Model Fit & \multicolumn{2}{|c|}{$\begin{array}{c}\text { External Sources of } \\
\text { Knowledge (EK) }\end{array}$} & \multicolumn{2}{c|}{$\begin{array}{c}\text { Strategic Talent } \\
\text { Management (TM) }\end{array}$} \\
\cline { 2 - 6 } & $\mathrm{R}^{2}$ & $\beta$ & $\begin{array}{c}\text { Odds } \\
\text { Ratio }\end{array}$ & $\beta$ & $\begin{array}{c}\text { Odds } \\
\text { Ratio }\end{array}$ \\
\hline Regressing TM on EK & 0.28 & $0.43(0.00)$ & --- & --- & --- \\
\hline Client Base Expansion (CBE) & & & & & \\
Restricted Model & 0.280 & $0.532(0.05)$ & 1.70 & & \\
Full Model & 0.448 & $0.171(0.58)$ & 1.19 & 1.286 & 3.62 \\
Difference & +0.168 & -0.361 & -0.51 & $(0.00)$ & \\
\hline Client Base Retention (CBR) & & & & & \\
Restricted Model & 0.178 & $0.553(0.04)$ & 1.74 & & \\
Full Model & 0.402 & $0.075(0.80)$ & 1.08 & 1.431 & 4.19 \\
Difference & +0.224 & -0.478 & -0.66 & $(0.00)$ & \\
\hline Total Revenue Growth (TRG) & & & & & \\
Restricted Model & 0.291 & $0.964(0.00)$ & 2.62 & & \\
Full Model & 0.408 & $0.662(0.01)$ & 1.94 & 1.034 & 2.81 \\
Difference & +0.117 & -0.302 & -0.68 & $(0.00)$ & \\
\hline Overall Business Growth (OBG) & & & & & \\
Restricted Model & 0.370 & $1.144(0.00)$ & 3.14 & & \\
Full Model & 0.523 & $0.830(0.01)$ & 2.29 & 1.332 & 3.79 \\
Difference & +0.153 & -0.314 & -0.85 & $(0.00)$ & \\
\hline
\end{tabular}

Note: Figures in parentheses denote significance levels. 